
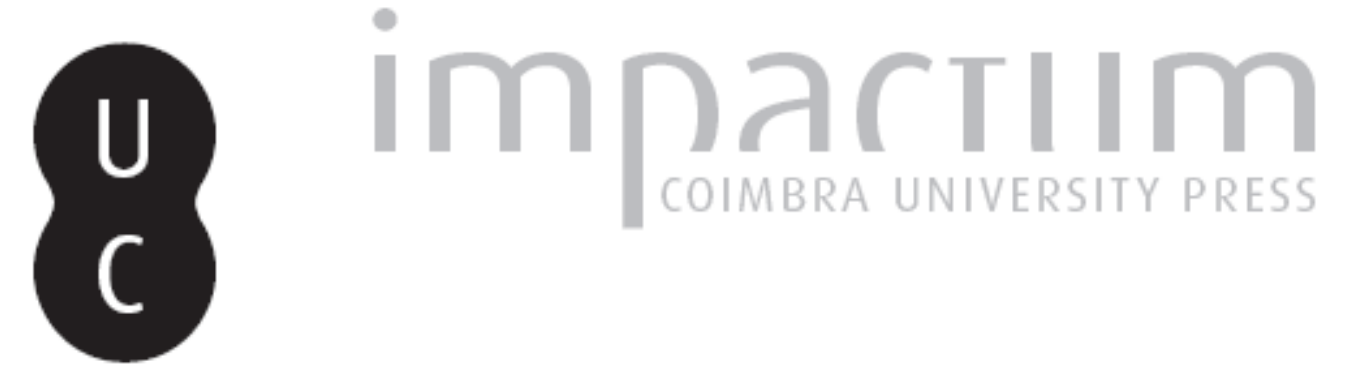

\title{
Alexandre Herculano: a história, os documentos e os arquivos no século XIX
}

Autor(es): $\quad$ Coelho, Maria Helena da Cruz

$\begin{array}{ll}\text { Publicado por: } & \text { Faculdade de Letras da Universidade de Coimbra, Instituto de História } \\ \text { Económica e Social }\end{array}$

URL

persistente:

URI:http://hdl.handle.net/10316.2/27893

DOI:

DOI:http://dx.doi.org/10.14195/0870-4147_42_2

Accessed : $\quad$ 26-Apr-2023 09:12:06

A navegação consulta e descarregamento dos títulos inseridos nas Bibliotecas Digitais UC Digitalis, UC Pombalina e UC Impactum, pressupõem a aceitação plena e sem reservas dos Termos e Condições de Uso destas Bibliotecas Digitais, disponíveis em https://digitalis.uc.pt/pt-pt/termos.

Conforme exposto nos referidos Termos e Condições de Uso, o descarregamento de títulos de acesso restrito requer uma licença válida de autorização devendo o utilizador aceder ao(s) documento(s) a partir de um endereço de IP da instituição detentora da supramencionada licença.

Ao utilizador é apenas permitido o descarregamento para uso pessoal, pelo que o emprego do(s) título(s) descarregado(s) para outro fim, designadamente comercial, carece de autorização do respetivo autor ou editor da obra.

Na medida em que todas as obras da UC Digitalis se encontram protegidas pelo Código do Direito de Autor e Direitos Conexos e demais legislação aplicável, toda a cópia, parcial ou total, deste documento, nos casos em que é legalmente admitida, deverá conter ou fazer-se acompanhar por este aviso.

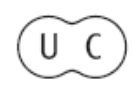





\title{
Alexandre Herculano: a história, os documentos e os arquivos no século XIX
}

\author{
Maria Helena da Cruz Coelho \\ Faculdade de Letras da Universidade de Coimbra \\ Centro de História da Sociedade e da Cultura - FLUC \\ chsc@ci.uc.pt
}

Resumo:

Neste estudo parte-se do pensamento de Alexandre Herculano sobre o sentido da história e o seu paradigma de cientificidade e procura da verdade histórica para se atentar na sua metodologia de investigação documental na construção do trabalho histórico. Percorrese o seu trilho de pesquisa e selecção de pergaminhos que empreendeu nos cartórios do centro e norte do país, nas viagens que realizou em 1853 e 1854, como membro da Academia das Ciências de Lisboa. Conhecem-se as suas ideias sobre a recolha desses testemunhos na Torre do Tombo, arquivo em que muito investigou. Paralelamente aborda-se a sua liderança e acção no projecto concretizado de publicação dos documentos mais antigos nos Portugaliae Monumenta Historica, assim se evidenciando o vasto labor heurístico e de acessibilização documental do historiador e cientista Alexandre Herculano, em perfeita consonância com o que de mais avançado ocorria na Europa de Oitocentos.

Palavras chave:

Historiografia; Alexandre Herculano; Documento; Arquivos; Academias.
Abstract:

The starting point of this study is the thought of Alexandre Herculano about the meaning of History as well as his paradigm of scientificity and search for historical truth: then we focus on his methodology of documental research in the making of historical work. We follow the paths he travelled, as a member of the Academy of Sciences of Lisbon, in 1853 and 1854, to search and select parchments in various archives of central and northern Portugal. We reach his ideas about collecting such evidence in the National Archive (Torre do Tombo), where he researched so much. In parallel, we address his leadership and action in the realized project of publishing the most ancient documents in the Portugaliae Monumenta Historica, thus emphasizing the vast work in finding and making accessible historical documents accomplished by Alexandre Herculano, the historian and scientist, in perfect consonance with the leading ideas of $19^{\text {th }}$ century Europe.

Keywords:

Historiography; Alexandre Herculano; Document; Archives; Academies. 
Herculano, um romântico e um liberal, comungava dos ideais de convergência num projecto de educação nacional, travejado pela história, aliada à literatura e à moral, que visasse formar as gerações no amor da Nação, que se queria assente em bases representativas. Logo, o apelo às origens, buscando a "alma nacional" nos costumes, na cultura popular, nos monumentos, na história, fundamentava o compromisso com um grande movimento nacionalizador ${ }^{1}$.

A valorização do passado, sem qualquer atitude saudosista, conduzia ao dinâmico empenhamento social do seu tempo. No conhecimento histórico encontrava muitas vezes as armas para a crítica do presente, não sem demonstrar, pontualmente, algum comprazimento com certos recortes do passado mais edificantes que os da sua época.

Cada novo desafio de acção política - reforma educativa, reforma social, reforma do direito - impelia Herculano a olhar o passado e a buscar nele a luz e a bússola para a "regeneração" da Nação². O mergulho nas raízes vivificaria e nacionalizaria as consciências. E assim, a história invadia qualquer manifestação cultural. Dos romances à poesia e do teatro à polémica, relevava um objectivo eminentemente prático de "corrigir e alumiar o presente" ${ }^{3}$.

1. O novo paradigma histórico de cientificidade e da procura da verdade histórica, que Herculano perseguia, não era, pois, descomprometido ideologicamente. A sua prática historiográfica norteava-se por valores éticos, educativos e cívicos, que davam sentido ao patriotismo e apontavam o caminho do fomento no presente e no futuro ${ }^{4}$. Por isso declarava sem rodeios: "depois da revolução que, sobre as ruínas da sociedade antiga, constituiu neste país a sociedade

1 Uma multifacetada abordagem do pensamento histórico de Herculano se colhe no estudo de Fernando Catroga, "Alexandre Herculano e o historicismo romântico", in Luís Reis Torgal, José Maria Amado Mendes, Fernando Catroga, História da História em Portugal. Sécs. XIX-XX, Lisboa, Círculo de Leitores, 1996, p. 39-85. Mais recentemente, a sua vertente de cidadão e historiador foi aprofundada por Vitorino Magalhães Godinho, no estudo "Herculano, o cidadão e o historiador no mundo do progresso", in Alexandre Herculano. O Cidadão e o Historiador. Antologia, organização de Vitorino Magalhães Godinho e Eurico Gomes Dias, Lisboa, Imprensa Nacional-Casa da Moeda, 2010, p. 7-96.

2 Este comprometimento entre o estudo, a obra e a cidadania em Herculano é bem evidenciado no trabalho de Guilherme d'Oliveira Martins, Alexandre Herculano: Mestre-Cidadão, Lisboa, Imprensa Nacional-Casa da Moeda, 2010.

3 Prefácio da terceira edição da sua História de Portugal, datado de 1863, (Alexandre Herculano, História de Portugal desde o começo da monarquia até o fim do reinado de Afonso III, prefácio e notas críticas de José Mattoso, verificação do texto de Ayala Monteiro, I, Lisboa, Livraria Bertrand, 1980, p. 4).

4 Sobre a sua concepção do homem, da cidadania e sobre a visão que tinha dos problemas de Portugal no seu tempo, leia-se Vitorino Magalhães Godinho, “art. cit.”, p. 19-53. 
moderna, fui eu, se não me engano, o primeiro que proclamei a possibilidade e a necessidade de conciliar o amor dos foros de homens livres com a veneração ás tradições gloriosas e sanctas do passado, ao que neste havia grande e bello e era muito" .

A sua divulgação da história dispersa-se por muitos artigos que escreveu em periódicos ou pela acessibilização ficcionada traduzida em romances e mesmo em dramas históricos ${ }^{6}$. Escritos que, diga-se, tinham o mesmo referente de fontes de uma nova cultura e educação, com objectivos de melhorar o presente, na convicção da "historia magister vitae".

A sua produção historiográfica mais relevante consubstancia-se, porém, essencialmente, na sua História de Portugal, em 4 volumes, saída entre 1846 e $1853^{7}$.

Nela se espelha a sua propensão para uma história social, que relativizava a dos indivíduos, visando uma história de pluralidade causal, de causalidade relacional e totalizadora. A sua vontade era escrever uma história objectiva, imparcial, descomprometida de preconceitos e ideologias, que lhe exigiam, para alcançar a verdade, o conhecimento e a crítica das fontes, que transformava os "monumentos" em documentos históricos ${ }^{8}$.

$\mathrm{Na}$ advertência à primeira edição traveja as ideias mestras da sua teoria da história.

5 Alexandre Herculano, Cartas, t. I, Lisboa, Allaud, Alves Bastos \& C Editores, s. d., p. 256, carta à Academia de 6 de Abril de 1868 .

6 Vitorino Magalhães Godinho, "art. cit.", p. 67-82, aludindo à interpretação da sociedade global na obra de Herculano, escreve com toda a pertinência: "Herculano, quando escrevia os romances históricos, escrevia ao mesmo tempo a parte dos personagens e acontecimentos da sua obra histórica" (p. 71).

7 Joaquim Veríssimo Serrão no estudo, “A ‘História de Portugal”, in Herculano e a consciência do liberalismo português, Lisboa, Bertrand, 1977, p. 97-112, ao analisar a metodologia e teorias subjacentes a esta obra, expondo as informações bibliográficas e documentais que a suportam, afirma: "A base da sua investigação representa um considerável acervo de documentos desde as fontes do Arquivo Régio às velhas crónicas leonesas e compostelanas, sem esquecer os textos literários e religiosos" (p.98), indicando os materiais recolhidos no arquivo da Torre do Tombo e na Universidade de Coimbra, na Biblioteca Pública de Évora e no arquivo catedralício de Braga.

8 Ao dar a conhecer o ofício de historiador em Herculano, nas suas forças mas também ambiguidades, Vitorino Magalhães Godinho, “art. cit.”, p. 53-67, releva o seu trabalho de compilador e crítico dos documentos, afirmando que "na construção da história é afinal a metodologia da ciência que o orienta" (p. 65). E explicita "quer dizer que dos exames dos factos que as fontes nos mostram passamos à elaboração de hipóteses, de que deduzimos consequências a verificar de novo pelo exame dessas fontes. Nesse trabalho temos de atender à dedução das consequências dos sucessos históricos, tendo como fio leis gerais que periodizam a história das sociedades" (p. 66). 
A história é uma ciência que tem por objectivo "averiguar qual foi a existência das gerações que passaram", tendo como fim a verdade, sendo que, como diz, "a verdade histórica é só uma". No entanto, esta sua premissa de objectividade histórica, que não deixava de envolver certas ambiguidades ${ }^{9}$, surge já algo matizada no seu pensamento com a subjectividade do historiador, quando declara: "porque eu escrevo apenas para os singelos amigos da verdade, e ainda receoso, apesar da pureza dos meus desejos, de não ser exacto, ou pela escasseza dos documentos, ou por engano próprio na apreciação dos factos".

Esta busca de uma história científica e verdadeira visava derrubar barreiras ideológicas nacionalistas, pelo que afirmava: "tenho fé que não me cegou malevolência para com os estranhos, nem parcialidade pela terra natal". Correlativamente, intentava pôr fim a mitos, lendas, sucessos maravilhosos e fábulas, abjurando aqueles que, como refere com fina ironia, "seriam capazes de tomar por matéria histórica as lendas de As Mil e Uma Noites, se lá encontrassem alguma que lhes lisonjeasse o apetite".

Para escrever a história era necessário percorrer arquivos e bibliotecas, ler documentos nacionais e estrangeiros, "avivar as inscrições, conhecer os cartórios particulares das catedrais, dos municípios e dos mosteiros", sendo, em simultâneo, como declara, "paleógrafo, antiquário, viajante, bibliógrafo, tudo". Pugnava, então, pela publicação de colecções impressas de monumentos históricos, como se fazia nos demais países europeus ${ }^{10}$, o que já relevaremos.

A história servia, na proposta de Herculano, para a refundação da Nação que, dada a sua decadência, precisava de se regenerar. Justamente no pensamento romântico, a especificidade nacional remontava às origens, fundamento e raiz da sua verdadeira essência. Logo, esse percurso desembocava na valorização da Idade Média, tempo de gestação das línguas nacionais e dos povos modernos.

9 Vitorino Magalhães Godinho, “art. cit.", p. 99 anota assertivamente: "o pensamento de Herculano oscila, e é atravessado por contradições nem sempre resolvidas. Lembremos que ora se move na esfera da ciência, ora resvala para a ordem ética e afirma certas verdades absolutas, insere o absoluto na própria evolução histórica (a tendência inexorável para os arquétipos ideais)".

${ }^{10}$ Como afirma, na advertência da primeira edição da sua História: "As colecções impressas de monumentos históricos, que todos ou quase todos os países possuem, faltam neste nosso. Documentos avulsos, derramados por obras escritas mal podem, às vezes, pelo errado da sua leitura e por se acharem confundidos com diplomas forjados, ser aceites como autoridades seguras". Logo: "quem se ocupar da história portuguesa há-de sepultar-se nos arquivos "(Alexandre Herculano, História de Portugal, I, p. 19). 
E a sua História de Portugal, em 4 volumes, acabou mesmo por se confinar apenas ao período medieval, período ascendente e paradigmático da nossa história, em que o princípio da "liberdade" se conciliava com o da "variedade"

No primeiro volume trata das origens de Portugal desde o domínio árabe até ao final do governo de Afonso Henriques; no segundo avança pelos reinados de D. Sancho I, D. Afonso II e D. Sancho II; dedica o terceiro a D. Afonso III e a alguns aspectos da história social; já o quarto volume é todo ele centrado na instituição municipal e nos forais que a sancionavam, pois como assevera: "é dela que esperamos a regeneração do nosso país, quando de todo se rasgar o véu, já tão raro, das ilusões deste século". Para acrescentar: "em parte nenhuma, talvez, durante a Idade Média, teve mais influência no progresso da sociedade, foi mais enérgica e vivaz do que em Portugal" 12 .

Nessa obra, refutando as teses tradicionais e as explicações milagrosas da Nação portuguesa, Herculano defende uma secularização das origens de Portugal. Contrariando os argumentos, comummente aceites, da raça, da língua e do território como fundamentos nacionais e, portanto, a crença da descendência portuguesa dos Lusitanos, virá a afirmar que o reino de Portugal se formou pelos dois meios da revolução e da conquista ${ }^{13}$. Sustenta, pois, a teoria "voluntarista" da génese de Portugal, que suscitou, desde logo, aderentes e contraditores ${ }^{14}$. Mais se insurge contra os "mitos fundadores" do milagre de Ourique e das Cortes de Lamego, desmistificando o apoio divino e a teoria contratualista da nossa nacionalidade ${ }^{15}$.

A crítica ao ultramontanismo, conservador e socialmente centralista, e as suas convicções liberais descentralizadoras levam-no a evidenciar na sua história, de pendor político e institucional, o passado dos municípios, como já dissemos, porque a unidade nacional não podia destruir a "variedade comunal". Na senda de Thierry, Guizot e Tocqueville, defendia que a "comuna medieval", sede da

${ }^{11}$ Fernando Catroga, “art. cit.”, p. 81. Vitorino Magalhães Godinho, “art. cit.”, p. 82-96, analisa esta obra, atentando nos seus principais e mais inovadores tópicos - lusitanos, milagre de Ourique, concelhos, feudalismo - e, num âmbito abrangente, na concepção global de Herculano sobre a história de Portugal e sua periodização, mostrando certas incapacidades operatórias deste historiador para a compreensão de alguns períodos históricos e complexos sociais.

${ }_{12}$ Alexandre Herculano, História de Portugal, vol. IV, p. 34.

${ }_{13}$ Alexandre Herculano, História de Portugal, vol. I, p. 80, 41, 82-83.

${ }^{14}$ Cfr. Sérgio Campos Matos, Historiografia e Memória Nacional. 1846-1898, Lisboa, Edições Colibri, 1998, p. 315-320; Fernando Catroga, "art. cit.", pp. 70-72.

${ }^{15}$ Sobre a questão do milagre de Ourique na obra de Herculano leia-se Ana Isabel Buescu, O milagre de Ourique e a História de Portugal de Alexandre Herculano. Uma polémica oitocentista, Lisboa, Instituto Nacional de Investigação Científica, 1987. Uma análise da historiografia em torno destas tradições lendárias apresenta Sérgio Campos Matos, ob. cit., p. 261-273. 
burguesia, era a raiz da moderna classe média. Acreditava que, na equilibrada coexistência descentralizada entre o poder municipal e o poder senhorial, se corporizava a essência política da sociedade portuguesa, nesse ciclo ascendente das origens de Portugal. Logo, dado que no seu tempo via "definhados e moribundos, os restos das instituições municipais, que o absolutismo (nos) deixara", a propriedade estava mal organizada e a agricultura, que era, segundo ele, a verdadeira indústria de Portugal, encontrava-se em decadência ${ }^{16}$.

Como escreve Veríssimo Serrão: "O município surgia-lhe como a forma de organização comunitária que ajudara a erguer os estados saídos da Reconquista Cristã, aceitando a sua origem romana e a sua manutenção ao longo dos períodos visigótico e sarraceno. O êxito das lutas contra os mouros, o fortalecimento da autoridade contra o poder senhorial, o progresso dos centros urbanos e o surto da vida agrícola tinham resultado, no seu entender, da acção desses 'grémios populares' agrupados em concelhos que fortaleceram a vida económica e social e o povoamento do reino"17.

Se hoje as ideias de Herculano, de um município vindo da herança romana, de um município democrático e participativo, não são já admissíveis, no entanto a sua análise jurídico-normativa das cartas de foral continua a ter relevância e, como mérito maior, devemos-lhe o interesse pelo estudo dos concelhos em tempos medievais.

$\mathrm{Na}$ escrita deste volume da História de Portugal, sentindo-se inseguro perante certas questões jurídicas, pediu mesmo um parecer à Faculdade de Direito de Coimbra, demonstrado o respeito que Herculano lhe devotava ${ }^{18}$, parecer que lhe foi inteiramente favorável e que muito o gratificou ${ }^{19}$.

2. Abordemos agora um outro aspecto com este intimamente relacionado, que verdadeiramente queremos destacar.

Como bem se compreende, a investigação documental e a construção histórica interpenetram-se no labor de Herculano, sobremaneira para dar corpo à erudita e crítica História de Portugal.

${ }^{16}$ Joaquim Veríssimo Serrão, "Viagens em Portugal (1853-1854)”, in ob. cit, p. 154.

17 Joaquim Veríssimo Serrão, “A ‘História de Portugal”, in ob. cit., p. 102-103.

${ }^{18}$ As relações de Herculano com a Faculdade de Direito de Coimbra são tratadas por António Baião na segunda parte do seu estudo, "Herculano Inédito", O Instituto, 115, Coimbra, 1953, p. 131-145.

${ }^{19}$ Joaquim Veríssimo Serrão, “A ‘História de Portugal”, in ob. cit., p. 103-104. 
Atentemos, antes de mais, nos conhecimentos de que dispunha Herculano para abraçar o caminho da investigação, da crítica documental e da história científica $^{20}$.

Fizera uma aprendizagem escolar na Congregação dos Oratorianos, tendo como objectivo a entrada na Universidade. Uma quebra nas finanças familiares não lhe veio a permitir essa formação universitária. Viu-se desviado para uma preparação mais prática, cursando, em 1825, Matemática na Escola Naval e frequentando a Aula do Comércio, que lhe deram conhecimentos de economia, contabilidade e estatística. Sabia ainda línguas, do latim às línguas vivas, como francês, alemão (o que era pouco vulgar), espanhol e italiano. A sua vocação literária tinha sido altamente enriquecida com a frequência do círculo literário da Marquesa de Alorna.

Foi também aluno, no ano de 1830-1831, da aula de Diplomática, que existia na Torre do Tombo, regida por Francisco Ribeiro Dosguimarães, acrescentando-lhe competências das ciências paleográfica e diplomática, que o habilitavam para a crítica documental. Aí terá tomado contacto com os estudos de Mabillon e de outros fundadores da ciência diplomática, como igualmente com as obras de João Pedro Ribeiro, que lançou em Portugal os fundamentos científicos dessa disciplina. Estava, pois, apetrechado com o saber das escritas antigas e da crítica interna e externa das cartas, que tinha em vista, na época, averiguar a veracidade ou falsidade dos documentos.

Se o seu domínio de línguas lhe permitia já ler autores alemães (Niebuhr, Ranke) e franceses (Thierry, Guizot, Savigny) ${ }^{21}$, o seu comprometimento político com o liberalismo forçou-o, depois da sublevação antimiguelista de 1831, a exilar-se, rumando até países europeus. Esteve na Inglaterra, em Plymouth, na ilha de Jersey e em França. Neste país, nas bibliotecas de Rennes e Paris, terá aprofundado o seu conhecimento sobre a cultura francesa e sobretudo a sua formação histórica, com a leitura das obras dos historiadores liberais como Thierry e Guizot.

Retornado aos Açores, em Fevereiro de 1832, virá logo depois, em Julho, a integrar o exército liberal que desembarcou no Mindelo e entrou no Porto, participando na defesa desta cidade durante o cerco miguelista.

${ }^{20}$ Sobre o tema leia-se Vitorino Nemésio, A mocidade de Herculano até à volta do exílio, Lisboa, Bertrand, 1934 (última edição, com prólogo de Luís Oliveira Ramos, Lisboa, Imprensa Nacional-Casa da Moeda, 2003); Joaquim Veríssimo Serrão, "Formação cultural", in ob. cit., p. 41-56; Vitorino Magalhães Godinho, "art. cit.”, p. 12-15.

${ }^{21}$ Quanto às obras da historiografia alemã, francesa e italiana que influenciaram a obra histórica de Herculano, veja-se Fernando Catroga, "art. cit.", p. 54-58. 
No ano seguinte, a 22 de Fevereiro, estava a ser nomeado segundo-bibliotecário da Biblioteca Pública do Porto. Nesse cargo começou, desde logo, nas áreas de domínio liberal, a reunir documentos e livros nos arquivos e bibliotecas eclesiásticas. Essa vontade de recolher os testemunhos do passado seria uma imperiosa necessidade para quem, como Herculano, queria "revolucionar" a ciência histórica, fundando-a na certeza dos factos e não em lendas e mitos, para atingir a verdade histórica, como acreditava.

Em consentâneo, os melhores exemplos europeus aconselhavam esse caminho. E os olhos de Herculano estariam sobremaneira fixados na Alemanha, se bem que não lhe seria desconhecida a criação em Paris, no ano de 1821, da École des Chartes, que se devotou ao ensino das ciências documentais e se empenhou na publicação de múltiplas colecções de manuscritos. Teria, no entanto, como modelo inspirador o projecto que Stein lançara, em 1819, na Alemanha, de editar os Monumenta Germaniae Historica, cujo primeiro volume saiu em 1826.

E a vida cada vez mais o vai aproximando dos documentos. Em 1836 será a cidade de Lisboa a recebê-lo. Na verdade, a 17 de Setembro, pede a demissão de bibliotecário da Biblioteca Pública do Porto e ruma à capital. Empenha-se, sobretudo desde 1837, como encarregado da redacção de O Panorama, órgão da Sociedade Propagadora dos Conhecimentos Úteis, em escrever, nas suas páginas, muitos artigos de diversa natureza. Dava assim corpo ao projecto de criar uma revista liberal, que difundisse a todas as classes de cidadãos um amplo espectro de conhecimentos com vista a uma instrução interclassista nacional.

Em Agosto de 1839 é nomeado Bibliotecário-mor de sua Majestade e dirige as Bibliotecas da Ajuda e das Necessidades, crescendo nele a vontade de se dedicar à investigação histórica.

Se deixa ao tempo a direcção de $O$ Panorama compromete-se com a política, sendo eleito deputado do Parlamento, pela oposição cartista do Porto, em Maio de 1840, e aí participa na Comissão Parlamentar da Instrução Pública. Mas o golpe de Estado de Costa Cabral e a restauração da Carta Constitucional em 1842, levam-no a afastar-se da vida política, tendo já no ano anterior abandonado as Cortes.

Nesta década de 40, o seu empenhamento na divulgação do passado, através da literatura e da história científica, é muito intenso ${ }^{22}$. Em 1843 publica, em folhetins, na revista $O$ Panorama, O Bobo. Em 1844 saem Eurico o

${ }^{22}$ As suas múltiplas actividades em torno das décadas de 40 e 50 são abordadas nas páginas de Joaquim Veríssimo Serrão, "Jornalista, Bibliotecário e Político”, in ob. cit., p. 57-79. 
Presbitero, O Pároco da Aldeia e Os Infantes em Ceuta. Em 1848 está a editar O Monge de Cister, saindo, em 1851, a compilação Lendas e Narrativas ${ }^{23}$.

Mas também nessa mesma década abre o seu ciclo histórico-científico e, em 1842, publica as Cartas sobre a História de Portugal ${ }^{24}$, nas quais se apresentam as linhas essenciais da futura História de Portugal. O primeiro volume desta sua obra mestra sai a lume em $1846^{25}$, esgotando-se logo nesse ano, para os outros se lhe seguirem em 1847, 1850 e 1853.

Mas, ainda antes de toda esta sua prodigiosa actividade, já o seu muito saber e vasta cultura e a sua acção política e de escrita lhe haviam granjeado prestígio e respeito, vindo a ser nomeado, quando tinha apenas 34 anos, sócio correspondente da Academia Real das Ciências de Lisboa ${ }^{26}$. Para oito anos depois, em 1852, se tornar sócio efectivo ${ }^{27}$.

E foi impulsionado por esta instituição que, na década de 50, Herculano, que primeiro se comprometera com o movimento da Regeneração e depois,

${ }^{23}$ Romances caracterizados, no seu conjunto, por Joaquim Veríssimo Serrão, "O Romance Histórico", in ob.cit.,pp. 177-191. Uma actualizada e sugestiva análise destas obras se colhe em Maria Helena Santana, "Introdução", in Alexandre Herculano. O Escritor. Antologia, organização de António M. B. Machado Pires e Maria Helena Santana, Lisboa, Imprensa Nacional-Casa da Moeda, 2010, p. 11-49.

${ }^{24}$ Uma sinopse do conteúdo desta cartas, que abordam, entre outros temas, as divisões cronológicas da nossa história, apresenta Joaquim Veríssimo Serrão, ““As Cinco Cartas’ sobre a História de Portugal", in ob. cit., p. 81-95.

${ }^{25}$ Para elaborar a sua História muito trabalhou no arquivo da Torre do Tombo, onde era oficial maior José Manuel Severo Basto. Assim, logo que saiu este primeiro volume, oferece-lho. Na carta que lhe escreve na ocasião, acrescenta que não o poderá dar a todos os seus amigos do arquivo, mas admite que Severo Basto lhes "facultara o uso delle, se julgarem que vale a pena de se ocuparem com isso, do que eu próprio não tenho muita certeza" (TT- Monumento a Alexandre Herculano, caixa 3, n. 6). Cfr. António Baião, “Alexandre Herculano e a Torre do Tombo", in Homenagem ao Mestre, Coimbra, Imprensa da Universidade, 1910, p. 4-5.

${ }^{26}$ Como se sabe, Alexandre Herculano de Carvalho e Araújo nasceu em Lisboa, a 28 de Março de 1810. Foi proposto na sessão de 31 de Janeiro de 1844 e aprovado por unanimidade, no ano seguinte, na sessão de 21 de Fevereiro, tendo sido escolhido, a 19 de Junho, para membro da Comissão de História. Em carta de 24 de Fevereiro de 1844 agradece ao secretário perpétuo da Academia, Joaquim José da Costa Macedo, essa nomeação para sócio correspondente da Academia (Alexandre Herculano, Cartas, t. I, p. 243-244).

${ }^{27}$ A 2 de Janeiro de 1851, dada a distância da sua residência, que o impedia de ir a muitas sessões, ainda pedira que "o meu (seu) nome seja (fosse) riscado do catálogo dos sócios da Academia Real das Sciencias de Lisboa (Cartas, t. I, p. 247-248), mas a Academia não aceitou o seu pedido (Joaquim Veríssimo Serrão, "Os 'Portugaliae Monumenta Historica'”, in ob. cit., p. 122). 
na pós-regeneração, se refugiara no seu liberalismo utópico ${ }^{28}$, se veio a dedicar com grande intensidade à pesquisa documental.

É certo que a sua presença na Academia conheceu alguns tumultos, dado os desentendimentos com Costa Macedo, secretário perpétuo da Academia e depois, em 1856, guarda-mor da Torre do Tombo. Herculano, eleito Vice-Presidente da Academia e seu sócio de mérito ${ }^{29}$, acabará por se afastar dela nesse $a^{30} \mathrm{o}^{30}$. Os incidentes só ficarão de todo sanados quando Costa Macedo se aposentou do cargo da Torre do Tombo, em Agosto de $1857^{31}$.

Em 1852, a Academia Real das Ciências indigitou-o para dirigir a publicação dos documentos medievais portugueses do século VIII ao XV, iniciativa que ele próprio propusera, no início desse ano $^{32}$. Foi então que, como comissário

${ }^{28}$ Uma matização do liberalismo de Herculano, nas suas formulações políticas e sociais, encontra-se no estudo de Joaquim Veríssimo Serrão, "A ideologia política e social de Herculano", in ob. cit., p.193-211.

${ }^{29}$ Eleito Vice-Presidente a 31 de Janeiro de 1855, roga dispensa a 8 de Março, alegando os seus serviços literários, mas houve nova eleição e Alexandre Herculano viu-se reeleito. Foi aceite como sócio de mérito, em 14 de Junho. Nomeado Costa Macedo, a 26 de Março de 1856, para guarda-mor da Torre do Tombo, as questões agudizaram-se, ainda que a Academia, na maior parte dos seus sócios, estivesse ao lado de Herculano e o tivesse eleito de novo para Vice-Presidente nesse ano de 1856. (Um análise pormenorizada de todo este relacionamento com a Academia se colhe dos estudos de Christovam Ayres, "Alexandre Herculano e a Academia Real das Sciencias de Lisboa”, Boletim da Segunda Classe da Academia Real das Sciencias, vol. III, fasc. 3 (Março de 1910), p. 145-159 e António Baião, "Alexandre Herculano e a Academia (1844-1857)", Memorias da Academia das Ciências de Lisboa. Classe Letras, t. V, Lisboa, 1948, p. 491-514).

${ }^{30}$ Em carta de 27 de Dezembro de 1856, pede então que o libertem do cargo por achar que não tinha disponibilidade para levar a cabo as reformas que a Academia necessitava. $\mathrm{O}$ anterior exercício deste cargo, por mais de um ano, deram-lhe a saber que essa reforma não se compadecia com uma "fazenda desordenada", pois, como bem afirmava, "a vontade mais sincera de promover o progresso intellectual serão ineficazes, diante de insufficiencia dos recursos e da desordem administrativa". Mas assevera que "esteja a Academia certa de que nem por isso cessarão os trabalhos, ou esmorecerão os estudos a que especialmente me dediquei" (Alexandre Herculano, Cartas, t. I, p. 250-254).

${ }^{31}$ Em carta de 28 de Novembro de 1857, mostra-se assim disponível para reingressar na Academia e continuar os trabalhos que nela realizava (António Baião, "Alexandre Herculano e os Portugaliae Monumenta Historica. 1852 a 1873”, in Memorias da Academia da Ciências de Lisboa. Classe Letras, t. VI, Lisboa, 1957, p. 91-92).

32 Acresce que a Academia comunicou ao governo a proposta, que foi também por este apoiada (António Baião, "Alexandre Herculano e os Portugaliae Monumenta Historica", p. 51-52; Joaquim Veríssimo Serrão, “Os 'Portugaliae Monumenta Historcia'”, in ob. cit., p. 122). Constava da sua proposta: "que se fizesse uma collecção de documentos relativos à história social e política do nosso paiz desde o século VIII até os fins do XV”. E nesse inicial plano a obra só contaria com três secções: Monumentos Narrativos, Legislação e jurisprudência e Diplomas e actos públicos e particulares. 
da instituição e por ela subsidiado - ainda que não pago pelo seu trabalho ${ }^{33}$-, percorreu, nos anos de 1853 e 1854, acompanhado de Costa Basto ${ }^{34}$, primeiro os cartórios eclesiásticos da Beira e depois os do Minho, de que nos legou relevantes notas nos Apontamentos de Viagem ${ }^{35}$.

A sua consulta transporta-nos para a leitura da paisagem humanizada de Portugal em meados de Oitocentos, recheada de ricas e saborosas anotações sobre a história, o património e a cultura popular ${ }^{36}$. Mas se Herculano regista as etapas da sua viagem, omite muito do trabalho de pesquisa. Esse ressuma essencialmente das cartas dirigidas à Academia, muitas das quais António Baião publicou, ainda que sem esmiuçar o seu conteúdo ${ }^{37}$.

Retenhamos, pois, algumas informações concretas sobre os arquivos de igrejas e mosteiros que visitou e dos documentos que manuseou, muitas vezes em mau estado, dada a incúria dos seus detentores, o que lhe dava mais um

${ }^{33}$ Alexandre Herculano, Cartas, t. I, p. 275-276. Como afirma na carta à Academia de 14 de Março de 1871, reportando-se ao trabalho nas viagens e o que teve inicialmente com a edição dos Portugaliae: "o meu trabalho, então e subsequentemente, foi sempre gratuito, não obstante haver uma dotação especial que as Cortes votaram para aquela empresa" (p. 276). E na carta que escreve, a 15 de Setembro de 1853 (António Baião, "Alexandre Herculano e os Portugaliae Monumenta Historica”, p. 74-76), no terminus da sua primeira viagem ressalta bem o seu perfil escrupuloso, quando precisa: "tenho concluída a comissão que aceitei da Academia. Dos $150 \$ 000$ reis que recebi em três mesadas para as despesas da jornada sobejaram $8 \$ 900$ que remetto para entrarem de novo no cofre da mesma Academia". Mas, ao retomar a empresa, após os dissídios com Costa Macedo, passou a ser remunerado, como ele próprio o afirma: "tenho recebido a retribuição que me tem dado (a Academia) pelo serviço que me impuseram" (Alexandre Herculano, Cartas, t. I, p. 277).

${ }^{34}$ José Manuel da Costa Basto, paleógrafo da Torre do Tombo, era filho do oficial maior desse Arquivo, José Manuel Severo Aureliano Basto, e virá também ele a ser director da Torre do Tombo. Acompanhou Herculano nas duas viagens e algumas cartas escreveu sobre elas, sobretudo dirigidas a sua irmão João Basto (António Baião, “Alexandre Herculano e os Portugaliae Monumenta Historica”, p. 56-57, 69-70, 70-71, 73-74, 79-80, 82-83). Entretanto os académicos Costa Macedo, Barbosa Canais e Cunha Neves tinham como tarefa analisar os documentos impressos com interesse para a história medieval portuguesa.

${ }_{35}$ Pedro de Azevedo, "Apontamentos de viagem de Herculano pelo país em 1853 e 1854", Archivo Historico Portuguez, vol. IX (1914), p. 402-432.

${ }^{36}$ Joaquim Veríssimo Serrão, "Viagens em Portugal (1853-1854)”, in ob. cit., p. 135-157 desenvolve estes aspectos dos apontamentos. Por sua vez Vitorino Magalhães Godinho, "art. cit.", pp. 50-51, realça o facto destas viagens muito lhe servirem para conhecer o país real, dando consistência às suas críticas e propostas de acção política.

${ }^{37}$ António Baião, "Descrição do Castelo de Almourol”, Boletim da Academia das Ciências de Lisboa, vol. XXII (Março a Julho de 1950), p. 7-17; “Alexandre Herculano e os Portugaliae Monumenta Historica “, p. 51-98. No entanto, para a elaboração deste trabalho, tivemos contacto directo com estas cartas e as citações são feitas pelos originais. 
pretexto para a sua crítica contra o clero conservador ${ }^{38}$. Nestas viagens de trabalho, o historiador-investigador que era Herculano estava particularmente atento a todo o tipo de fontes, muito para além das escritas, que constituíam o alvo da sua missão, como, entre outros, os monumentos religiosos, militares ou civis, as inscrições em pedra, as moedas ou a cerâmica.

No ano de 1853, tendo inicialmente pesquisado na igreja de S. Salvador de Santarém, trabalhou, entre Junho e Julho, em Coimbra, nos cartórios da Sé, de Santa Cruz, dos conventos extintos, das colegiadas e da Fazenda da Universidade. Encontrou o cartório da catedral mal arrumado e sem índices, mas com documentos preciosos até ao século XIII, entre eles cinco enormes rolos de pergaminho, um pergaminho com os agravos do clero à Cortes de Guimarães, o cartulário designado por Livro Preto e os dois livros do obituário conhecidos como Livro das Calendas ${ }^{39}$. No arquivo do Governo Civil investigou os fundos dos mosteiros, assinalando que no de Santa Cruz se depositavam o Livro Santo, o Livro de D. João Teotónio e o Livro dos Forais, mas não o Livro da Noa, ainda que depois viesse a encontrar um Cronicão na posse do prior de S. Pedro ${ }^{40}$. Teve, ainda, a feliz surpresa de achar muitos velhos pergaminhos crúzios atrás de maços de documentos modernos ${ }^{41}$. Já com mágoa assinalou que os antiquíssimos documentos de Cete haviam desaparecido - vindo a encontrar depois um, do ano de 882, nas mãos de um particular ${ }^{42}$ - e que o convento da Graça só possuía documentação moderna.

${ }^{38}$ Esta crítica ao clero ultramontano, que se adensou com a publicação do volume primeiro da História de Portugal, em que Herculano negava, à luz da secularização das origens da nação portuguesa, o milagre de Ourique, espelha-se em múltiplas cartas que escreveu e ainda na obra Origem e Estabelecimento da Inquisição em Portugal, composta por três volumes, saídos entre 1854 e 1859 (Fernando Catroga, “art. cit.", p. 74-75; Joaquim Veríssimo Serrão, “A questão de Ourique" e "a 'História da Inquisição", in ob. cit., respectivamente, p. 113-120; 159-175).

${ }^{39}$ Carta de 6 de Julho de 1853. Herculano faz maços com a documentação que interessava, indicando o número de documentos em cada um deles, quer da que se encontrava nas gavetas, quer fora delas. Reúne os fragmentos de um processo entre a Sé e Santa Cruz do tempo de Afonso III, que diz ser relevante para estudar muitos factos dos reinados de Sancho I, Afonso II e Sancho II, "mas que sobretudo serve para a história da guerra da usurpação do conde de Bolonha". (António Baião, "Descrição do Castelo de Almourol”, p. 7-12).

${ }^{40}$ Em carta de 18 de Julho de 1853 relata minuciosamente este achado e as peripécias da recuperação do manuscrito ("Alexandre Herculano e os Portugaliae Monumenta Historica", p. 60-65).

${ }^{41}$ Carta de 18 de Julho de 1853.

${ }^{42} \mathrm{O}$ particular é, de novo, o prior de S. Pedro, homem curioso em Diplomática, como refere Herculano, mas muito pouco escrupuloso. Acabou, neste caso, por devolver o pergaminho e Herculano mandou-o logo para a Torre do Tombo (Carta de 18 de Julho de 1853). 
No cartório da Fazenda da Universidade guardavam-se os documentos de Pedroso, se bem que muito danificados pelo avivamento das letras com noz de galha $^{43}$, mas já na Câmara Municipal nada existia anterior a D. Dinis ${ }^{44}$.

Nos cartórios das colegiadas de Coimbra, que se apresentavam em estado vergonhoso, como afirmava ${ }^{45}$, encontrou, no entanto, mais documentos do que aqueles que João Pedro Ribeiro assinalara nas Observações Diplomáticas ${ }^{46}$. Em Celas, anotou a perda de muita documentação, no tempo das invasões francesas, ainda que alguma tivesse seleccionado para a obra em causa ${ }^{47}$.

De Coimbra Herculano alcançou Lorvão, referindo-se ao seu arquivo como tendo "arranjo e aceio" 48 , e nele viu vários códices - como o Livro dos Testamentos - e documentos avulsos ${ }^{49}$. Tocou-o o estado de miséria das freiras que ainda nele habitavam, como bem nos dá conta no opúsculo As freiras de Lorvão, conseguindo mesmo que o governo lhes viesse a conceder um subsídio. Passou também por Penacova (a 17 de Julho), onde examinou

${ }^{43}$ Carta de 18 de Julho de 1853.

${ }^{44}$ Carta de 7 de Julho de 1853 (António Baião, “Alexandre Herculano e os Portugaliae Monumenta Historica”, p. 59-60).

${ }^{45}$ Percorreu os cartórios das colegiadas de S. Pedro, S. Cristóvão, Santiago, S. João de Almedina, Salvador, S. Bartolomeu e Santa Justa, precisando: "o estado destes diversos cartórios é vergonhoso, exceptuando até certo ponto o de S. Pedro. Os pergaminhos estão lançados ao montão em arcas, ou em armários, cubertos de pó, sem ordem nem índices, nem resumos ou numeração regular. Em S. Christovam achei uma parte delles podres" (Carta de 18 de Julho). Na continuação da carta anterior, a 29 de Julho (António Baião, "Alexandre Herculano e os Portugaliae Monumenta Historica”, p. 65-66), anota que no cartório de S. Bartolomeu, para além de vários documentos encontrou um obituário do século XIII. Igualmente assinala que o cartório de Santa Justa estava bem organizado, ainda que tivesse pouco interesse para o período em causa.

${ }^{46}$ Assim refere: "Se a Classe comparar as minhas notas com o que o nosso fallecido consocio o Snr ${ }^{\circ}$ João Pedro Ribeiro escreveu acerca destas collegiadas nas Observações Diplomáticas verá que eu fui mais feliz que elle, apesar de ter decorrido meio século, e de se terem estragado e perdido nesse meio tempo bastantes documentos" (Carta de 18 de Julho).

${ }^{47}$ Dá-o a conhecer no acrescento à carta de 18 de Julho, já com data de 29 de Julho: “quando ahi fomos ja estávamos prevenidos de que elle padecera asás na invasão francesa, porque esteve enterrado. Entretanto ainda é de alguma consideração. O que resta conserva-se com certo arranjo. Tomou-se nota de todos os documentos que pertenciam á epocha de que tratamos".

${ }^{48}$ Pedro de Azevedo, “Apontamentos de viagem...”, p. 412.

49 Também o refere na carta de 18 de Julho. Acontece que, em 1862, João Pedro da Costa Basto fez nova recolha de documentação nas instituições de Coimbra de que resultou a incorporação de 323 pergaminhos e um códice de Celas, 1480 pergaminhos de Lorvão e um códice e 8720 pergaminhos, 19 códices, 6 fragmentos e 4 rolos do cabido da Sé e das colegiadas, como nos dá conta António Baião, "A segunda incorporação de pergaminhos coimbrãos na Torre do Tombo", Arquivo Coimbrão, vol. XIV (1956), p. 129-133, que publica duas cartas do referido paleógrafo. 
os documentos municipais, entre eles o seu foral manuelino, e pela Lousa ${ }^{50}$, bem como inspeccionou ainda o arquivo do mosteiro de Semide (21 de Julho) de "pouca importancia" 51 , como refere.

Herculano saiu de Coimbra, no final de Julho (30), e dirigiu-se a Viseu. Aí trabalhou no arquivo da Sé (4 a 11 de Agosto) ${ }^{52}$, para logo depois atravessar a região do Vouga e visitar o mosteiro de Ferreira de Aves (12 de Agosto), onde recolheu informações biográficas sobre Frei Joaquim de Santa Rosa Viterbo e seleccionou em torno de 50 documentos ${ }^{53}$. Percorreu em seguida as terras de Cima Côa, na esperança - que se mostrou vã - de "achar alguma cousa nos archivos desas velhas municipalidades", em que tanto acreditava, na sua ideologia descentralizadora e municipalista ${ }^{54}$. Entrou, por fim, na Guarda, a 22 de Agosto, tendo investigado, no arquivo catedralício, de 23 a 26 desse mês, ainda que com parcos resultados ${ }^{55}$.

${ }^{50}$ Ainda na carta de 18 de Julho escreve que, na Lousã, não encontrou documentação anterior a D. Dinis, mas cópias de cortes e de legislação de D. Fernando.

${ }^{51}$ Pedro de Azevedo, "Apontamentos de viagem", p. 413. E, como esclarece na carta de 18 de Julho, a maior parte da documentação perdeu-se com as invasões francesas.

${ }^{52}$ Em carta de 8 de Agosto de 1853 (António Baião, "Alexandre Herculano e os Portugaliae Monumenta Historica", p. 66-68), dá conta do incêndio ocorrido "ha poucos annos" no seminário episcopal, onde se reuniam os cartórios do distrito, incluindo o de Lamego, tendo-se perdido os pergaminhos de Salzedas, Tarouca, S. Pedro de Águias e S. Cristóvão de Lafões. Herculano desejava até que certos particulares tivessem retido alguns ilicitamente, como em Coimbra, para se poderem ter salvo. Na Mitra só se deparou com documentos modernos e na Câmara com cartas depois do século XVI. No cartório da Sé, ainda em pior estado que o de Coimbra, encontrou porém 400 documentos anteriores a 1280. O incêndio no seminário fá-lo anotar que, por tais vicissitudes, seria bom que a documentação se recolhesse à Torre do Tombo. No entanto, como especificava em carta de 10 de Agosto, achava que não a deviam pedir enquanto viajava, pois logo lhe dificultariam as investigações. (Idem, ibidem, p. 68-69). Curiosamente José Basto, numa carta dirigida ao seu irmão João, mostra como ficou impressionado com a vida cultural viseense, escrevendo que a cidade era "uma Lisboa em ponto pequeno" (Idem, ibidem, p. 69-70).

${ }^{53}$ José Basto, em carta de 15 de Agosto, para o seu irmão João, alude ao bom acolhimento das freiras do mosteiro, de que só restavam cinco, e a esta selecção de 50 e tantos pergaminhos dos séculos XII e XIII, enquanto Herculano se refere mais genericamente à escolha documental aí realizada, na carta de 15 de Setembro de 1853 (António Baião, “Alexandre Herculano e os Portugaliae Monumenta Historica", p. 70-71, 74-76).

${ }^{54}$ Carta de 7 de Julho de 1853. Na carta de 15 de Setembro, depois da passagem por Trancoso, Sabugal, Sortelha, Belmonte e Penamacor, reitera que nada se lhe deparou para tempos anteriores a D. Manuel.

${ }^{55} \mathrm{Na}$ carta de 15 de Setembro de 1853 refere que a maioria dos documentos foram atirados fora pelos franceses, através das janelas da casa capitular, tendo-se danificado com água e terra. Conservaram-se melhor uns quantos, que haviam sido levados para outro lugar por causa de uma demanda do cabido. Assinala, por fim, que "poucos restam dos relativos aos dous primeiros 
A sua viagem, em 1854, iniciou-se igualmente em Junho, mas agora por mar de Lisboa até ao Porto, onde chegou, no dia 21, e aí terá trabalhado até depois de meados de Julho, porque o cabido demorou muito tempo a dar-lhe acesso aos seus fundos ${ }^{56}$. Nos dias 21 a 23 de Julho deslocou-se a Arouca e pesquisou no arquivo do mosteiro, recolhendo cerca de 600 documentos, para além dos copiados no Livro de D. Maior Martins ${ }^{57}$. Nos dias 1 a 5 de Agosto encontrava-se já a investigar no arquivo da Mitra de Braga, que diz estar em "estado deplorável" 58 , e no do Cabido da Sé, não deixando de anotar os estigmas do conservadorismo do clero bracarense e dos costumes religiosos vigentes na terra. Em Guimarães, onde se deteve no arquivo da colegiada, entre 21 e 23 de Agosto, sofreu a resistência do chantre, e assinalava a falta do Livro de Mumadona ${ }^{59}$. Visitou também os mosteiros de Refóios, Rendufe, Vairão e Vila do Conde, embora não especifique os trabalhos de investigação, chegando mesmo a ir até Tuy.

3. Neste itinerário pelo norte e centro do país ter-lhe-ão passado pelas mãos mais de 120 mil documentos, como refere Gabriel Pereira ${ }^{60}$. Foram muitos destes documentos que, por portaria de 11 de Setembro de 1857, ingressaram na Torre

seculos da monarchia". No mosteiro de Aguiar nada encontrou. Por sua vez a documentação da Sé de Castelo Branco era demasiado moderna, como anota.

${ }^{56}$ Por isso escreve, a 28 de Junho de 1854, a pedir que a Secretaria da Justiça expedisse ordens para lhe facilitar o acesso dos arquivos eclesiásticos, já que, depois de ver os cartórios na Repartição da Fazenda e os códices da Biblioteca, poderia ficar sem trabalho. Reitera o pedido, em missiva de 2 de Julho, perpassada da sua fina ironia: "eu sinto ja aqui uma resistência dos padres, que anda no ar, e que veio provavelmente de Coimbra empurrada pelo vento sul. Forte sova levam os mariolas em eu acabando a correição, se por cá a Sancta Madre Igreja me não mandar pregar algum tiro no meio das serras". Especifica também nessa mesma carta que dos mosteiros extintos colheu 1000 documentos de Pendorada e de Grijó o cartulário Baio Ferrado. Por sua vez Costa Basto, em carta também de 2 de Julho, para seu irmão, afirma que se haviam deparado com muitos pergaminhos no fundo do Governo Civil, mas que segundo Herculano faltariam para cima de 10000 documentos (António Baião, "Alexandre Herculano e os Portugaliae Monumenta Historica", p. 78-80).

${ }^{57}$ Estava a trabalhar neles a 30 de Julho, como nos relata noutra carta, esperando ordens do governo a fim de lhe serem facultados os arquivos de Braga e Guimarães (António Baião, "Alexandre Herculano e os Portugaliae Monumenta Historica", p. 80-81).

${ }^{58}$ Pedro de Azevedo, “Apontamentos de viagem...”, p. 427.

${ }^{59}$ Pedro de Azevedo, “Apontamentos de viagem...,", p. 430-431.

60 "Jornadas de Alexandre Herculano", Boletim da Segunda Classe da Academia Real das Sciencias, vol. III, fasc. 3 (Março de 1910), p. 175. 
do Tombo ${ }^{61}$, para serem estudados pela comissão que estava encarregada de publicar os Portugaliae Monumenta Historica. Este acto legislativo obrigou-o porém, logo em 1857, a apresentar a refutação das acusações movidas pelas instituições eclesiásticas contra a recolha do seus documentos na Torre do Tombo. E fá-lo, em nome da Academia, já que fora ela a solicitar a transferência de tais documentos e a aconselhar a sua conservação no Arquivo. Nesse escrito, "Do estado dos arquivos eclesiásticos do reino" ${ }^{62}$, perpassado, como o assunto dava ensejo, de acerbas críticas ao clero ultramontano, Herculano dá a conhecer os principais argumentos de algumas instituições eclesiásticas para, em seguida, os contradizer.

Percebemos, de imediato, que as resistências não vieram dos prelados, louvando mesmo o académico a tradição cultural do episcopado português, mas sim de certos cabidos e sobretudo do clero monástico. Entre os primordiais fundamentos aduzidos pelo clero para a desobediência à portaria governamental, contavam-se o direito à propriedade dos documentos, a necessidade de os manter porque, na maioria, eram comprovativos de contratos onerosos ou a necessidade deles para realizar o inventário dos bens que, depois de uma resolução de Cortes, o governo ordenara.

Contrapõe Herculano que os velhos pergaminhos, que não estavam sequer inventariados nem se mostravam acessíveis à leitura dos membros das corporações, já não desempenhavam qualquer função probatória do património fundiário e também não eram necessários para o inventário dos bens. Temiam-se, porém, certas instituições de que tais actos pudessem servir de prova a proprietários ou colonos com quem mantinham litígios sobre direitos dominiais, resistindo à sua cedência.

Mais defendia Herculano que os cartórios das corporações de mão-morta se consideraram sempre arquivos públicos ${ }^{63}$ e os seus documentos constituíam-se em propriedade do Estado. Logo, ao permanecerem guardados no Arquivo Nacional, ficavam mais seguros que nos cartórios eclesiásticos em que se

${ }^{61}$ Mas já antes, para dar prosseguimento à colecção documental, Herculano estava a pedir, em 24 de Novembro de 1854, o Livro Santo, o obituário de S. Bartolomeu e o Livro das Calendas (António Baião, “Alexandre Herculano e os Portugaliae Monumenta Historica”, p. 84-85).

62 Alexandre Herculano, "Do Estado dos Arquivos Eclesiásticos do Reino e do Direito do Governo em relação aos documentos ainda neles existentes. Projecto de Consulta submetido à Segunda Classe da Academia Real das Ciências. 1857”, in Opúsculos, vol. I, organização, introdução e notas de Jorge Custódio e José Manuel Garcia, Lisboa, Editorial Presença, 1982, p. 131-149.

${ }^{63}$ Refere mesmo que antes de D. Fernando não havia arquivo do rei ou do Estado e os arquivos eclesiásticos cumpriam essa função. 
encontravam, podendo sempre as corporações servir-se deles, requerendo traslados autênticos.

Estas refutações adensavam-se com outras considerações e mesmo com a denúncia de atitudes incorrectas de diversas instituições, nomeando-se especificamente o cabido da Sé de Braga. Urgia, por isso, como advoga, "uma profunda reforma no sistema da educação do clero e de vigilância da parte do Governo sobre o modo como são providos os benefícios eclesiásticos" ${ }^{64}$.

Fundamenta, ainda, o parecer da Academia no sentido de se conservarem no Arquivo da Torre do Tombo os documentos mais antigos e preciosos das corporações, tanto das extintas como das existentes, depois de utilizados pela Academia, enunciando o estado de incúria dos arquivos e documentos eclesiásticos e os perigos a que estavam sujeitos. Refere, então, que os documentos não se apresentavam, no geral, arrumados ou não havia nenhuma ordem lógica na arrumação; também não possuíam índices que facilitassem a sua consulta; alguns tinham nas costas a palavra "inútil", mostrando como as corporações os relegavam por já não terem interesse material; outros viram a sua escrita avivada com noz de galha por algum curioso, a qual deixava uma mancha negra, impedindo posteriores leituras.

Muitos cartórios encontravam-se expostos à chuva e nenhum estava resguardado contra incêndios, salientado que, devido às chamas, se haviam perdido os documentos de Salzedas, Tarouca, S. Pedro de Águias e S. Cristóvão de Lafões e os da Casa Pia do Porto, onde teriam sido consumidos os diplomas de quase todos os cartórios monásticos do Minho. Nesses arquivos locais os documentos ficavam sujeitos às devastações das guerras civis e estrangeiras ou, ainda mais grave, propensos à "deterioração permanente que o desleixo e a ignorância produzem(iam)" "Ex. Exemplifica tal desleixo e ignorância com casos concretos, muito em particular o corte de selos pendentes dos pergaminhos, porque impediam a encadernação dos mesmos, que uma corporação intentara levar a cabo. E neste particular escreve, com uma acintosa ironia, "os selos, sobretudo os dos diplomas pontifícios, esperam pela trombeta final do arcanjo para se unirem aos respectivos corpos, por que só a trombeta final poderá operar tal maravilha" 66 .

Esta polémica sobre a arquivação nacional dos documentos da Igreja, que então ocorreu, ainda hoje, como bem se sabe, não é pacífica. Conforme as teses assim uns se inclinarão para os argumentos do clero e outros para os que

\footnotetext{
${ }^{64}$ Alexandre Herculano, "Do Estado dos Arquivos Eclesiásticos do Reino”, p. 138.

${ }^{65}$ Idem, ibidem, p. 147.

${ }^{66}$ Idem, ibidem, p. 148.
} 
Herculano formulou em nome da Academia. Será, porém, de ponderar que sem esta recolha, o nosso património escrito seria hoje bem mais escasso.

Certo é que o acesso à rica documentação eclesiástica para fazer avançar o conhecimentos científico já de tempos anteriores se vinha a fazer sentir. Assim, no governo de D. João V, fora permitido que a Academia de História consultasse e copiasse os documentos das corporações eclesiásticas, da mesma forma que estas teriam de enviar à referida instituição um inventário de todos eles. Por sua vez, nos estatutos da Universidade determinava-se que os cartórios monásticos e catedralícios deviam estar abertos aos professores de direito pátrio para colherem na documentação os ensinamentos que lhes fossem úteis ${ }^{67}$.

Será ainda de anotar que se Herculano insistia na transferência dos documentos para a Torre do Tombo, não menos se preocupava com este arquivo. Conhecemos, de facto, uma sua carta e relatórios em que dava sugestões para a reforma da Torre do Tombo no sentido de melhor racionalizar o funcionamento da instituição até com economia de meios ${ }^{68}$.

4. Recolhidos os documentos, impunha-se publicá-los, muito em particular os mais antigos e mais preciosos. Logo deviam ter reunido unanimidade de opiniões os resultados práticos da consulta e estudo dos documentos da Igreja por parte da Academia, traduzidos na magna publicação dos Portugaliae Monumenta Historica, que foi mesmo subsidiada pelo Estado ${ }^{69}$.

${ }^{67}$ Alexandre Herculano, "Do Estado dos Arquivos", p. 140 alude a estes factos para corroborar a sua opinião de serem públicos e não privados os arquivos eclesiásticos.

${ }^{68}$ TT - Monumento a Alexandre Herculano, caixa 3, docs. 2, 3 e 4. Agradecemos ao Senhor Director da Torre do Tombo, Dr. Silvestre Lacerda o conhecimento desta documentação. Na referida carta escreve Herculano: "alem de se pouparem os $400 \$ 000$ reis que se augmentaram em 1835 (verifique se foi neste anno) he ainda uma economia de $100 \$ 000$ reis e haverá catalogos bem feitos (porque até os antigos precisam [ser] reformados) e ensino de diplomática regular". Estas achegas teriam em vista, uma intenção de reforma do arquivo que poderia talvez situar-se entre 1837 e 1887 (cfr. Cândida Fernanda Antunes Ribeiro, O acesso à informação nos arquivos, Parte I, $O$ acesso à informação no quadro do desenvolvimento dos arquivos em Portugal, Porto, 1998 [tese de doutoramento], p. 514-519).

${ }^{69}$ Primeiro recebera um subsídio das Cortes, que veio a ser suprimido, tendo o Estado dispensado a verba de seis mil reis para a continuação das obras começadas pelo Visconde de Santarém e para a edição dos Portugaliae. Posteriormente nesta verba das Publicações Subsidiadas ainda se lhe acrescentaram os Monumentos relativos às colónias, o que deixava para a publicação dos Portugaliae apenas um terço do dinheiro, e, finalmente, ainda a verba se reduziu para um quarto, dado que também dela saía o montante para a publicação de um Dicionário. Herculano não geria o dinheiro, limitando-se a apresentar as contas das despesas e a não ultrapassar a dotação que lhe estava destinada (Alexandre Herculano, Cartas, t. I, p. 259, 263-266, 272-278). 
Os propósitos da obra - compaginação com os avanços europeus de recolha documental e serviço em prol da ciência histórica - são enunciados por Herculano logo no começo da sua edição: "a maior parte das nações da Europa tem procurado com grandes esforços e à custa de avultadas despezas colligir em vastos repositorios os monumentos das suas epochas anteriores Estão-se desenterrando diariamente do pó das bibliothecas e dos archivos monumentos desconhecidos, que vem modificar completamente muitas opiniões históricas, corrigir outras, e confirmar definitivamente outras. Por este meio a critica, exercida severa e imparcialmente sobre elementos seguros, póde apreciar bem o valor dos factos, tornando-se assim exequivel reduzir a historia a uma verdadeira sciencia, que habilite o presente e o futuro para tirarem vantagem das licções do passado"70.

Os Monumentos Históricos de Portugal copiavam, então, o modelo da colectânea documental alemã Monumenta Germaniae Historica, a que já aludimos. Stein, ao promovê-la, pretendia divulgar os documentos da Antiguidade à Idade Média e, tendo como moto "sanctus amor patriae dat animum", visava associar o nacionalismo romântico ao ensino escolar. Tal colecção, dirigida por G. H. Pertz, dividia-se em cinco áreas - Antiquitates, Diplomata, Epistolae, Leges e Scriptores.

Por sua vez os Portugaliae Monumenta Historica, que numa primeira fase deviam publicar as fontes portuguesas mais antigas até 1280 , gizara-se com quatro secções - Diplomata et Chartae, que incluía os documentos particulares e régios conhecidos, respeitantes ao futuro reino de Portugal do século IX até 1100; as Leges et Consuetudines, que englobavam as leis gerais do reino, desde o código visigótico e actas de concílios até à legislação de Afonso III e ainda os forais do século XI até 1279, bem como alguns foros e costumes locais do século XIII; os Scriptores, que publicavam os mais antigos anais e crónicas, hagiografias dos séculos XIII e XIV e os nobiliários medievais ou Livros de Linhagens dos séculos XII a XIV; e as Inquisitiones, que editavam as inquirições de D. Afonso II de 1220 e as de Afonso III em 1258.

Em vida de Herculano saíram a lume um volume dos Scriptores, um volume e princípio do segundo das Leges et Consuetudines e ainda os Diplomata et Chartae, embora Herculano já se encontrasse retirado em Vale de Lobos ${ }^{71}$,

${ }^{70}$ Portugaliae Monumenta Historica, vol. I, Scriptores, Olissipone, Typis Academicis, 1856, p. V-VI.

${ }^{71} \mathrm{O}$ sentido deste seu retiro para o campo foi analisado por Joaquim Veríssimo Serrão, “A 'maldição' de Vale de Lobos”, in ob. cit., p. 213-253. 
para onde foi em $1859^{72}$. Só depois da sua morte, em 1877 , se iniciou a publicação da secção referente às Inquirições.

Um pormenorizado balanço do andamento da obra e dos seus colaboradores apreende-se pela carta que enviou à Academia a 6 de Dezembro de 1856, quando dela saíu pelos dissídios com Costa Macedo $^{73}$, e por uma outra que subscreveu quando reingressou, de 15 de Março de $1857^{74}$.

O método de trabalho utilizado e até mesmo a reputação da obra na própria época ressuma de algumas outras Cartas de Herculano dirigidas à Academia.

Inventariada a documentação, depois das viagens de 1853 e $1854^{75}$, e recolhida na Torre do Tombo, aí era escolhida a que devia ser publicada e estudada $^{76}$. Só assim os documentos podiam ser transcritos pela comissão, que não se fiava em cópias de escrivães ou paleógrafos das corporações, que tantas vezes forjaram ou falsificaram documentos, como afirma, e só admitia

${ }^{72}$ Por carta de 7 de Novembro de 1868 e outras quatro não datadas, três dirigidas a João Basto e uma a José Basto, publicadas por António Baião, “Alexandre Herculano e os Portugaliae Monumenta Historica”, p. 92-97, a que se devem juntar outras mais de 6 de Abril de 1868, 10 e 22 de Novembro de 1869, 14 de Março de 1871 e 15 de Dezembro de 1872 (Alexandre Herculano, Cartas, p. 255-283), verifica-se como continuava a dirigir e a trabalhar na obra, mesmo à distância, conhecendo-se questões do seu financiamento, do seu avanço e as anotações do Mestre.

${ }^{73}$ António Baião, “Alexandre Herculano e os Portugaliae Monumenta Historica”, p. 87-89. Enumeram-se também os fundos documentais remetidos à Torre do Tombo e sabemos ainda que os prólogos da obra em latim eram escritos pelo cónego Félix da Silva Negrão e revistos por António José Viale. Somos igualmente informados que João Basto lia o Livro de Linhagens do códice do Colégio dos Nobres e o seu irmão José Basto transcrevia o obituário de S. Bartolomeu e o Cronicão de Coimbra.

${ }^{74}$ António Baião, “Alexandre Herculano e os Portugaliae Monumenta Historica”, pp. 89-91. Durante o período em que Herculano se ausentou da direcção da obra o trabalho reduziu-se a um paleógrafo. Para o relançar o Mestre entrega de empreitada a conclusão da leitura do Nobiliário por $28 \$ 000$ reis enquanto o paleógrafo efectivo concluiria a cópia do obituário de S. Bartolomeu. Entretanto continuava a chegar documentação à Torre do Tombo, que José Costa Basto conferia, e que ia sendo copiada.

75 Diz-nos Herculano no escrito "Do Estado dos Arquivos”, p. 136: “A Classe possuía já a este tempo (1857) um inventário sucinto de todos os documentos anteriores a essa data (1280), que ainda existem nos arquivos dos distritos centrais e setentrionais do reino, e que monta, a alguns milhares. Esse inventário fora feito por um comissário da Academia com autorização do Governo, nos anos de 1853 e 1854”. O comissário havia sido, evidentemente, ele próprio.

76 Alexandre Herculano, "Do Estado dos Arquivos", p. 137. Salienta que a comissão pediu para os documentos irem para o Arquivo nacional, onde estariam seguros, e não para a Academia, onde seria mais cómodo à comissão trabalhar, exactamente para que não corressem riscos de extravio ou incêndio (Idem, ibidem, p. 141). 
"a conferencia pessoal das cópias destinadas à publicação com os respectivos originais, depois de terem apreciado quais merecem(iam) ver a luz pública"77.

Quando havia necessidade mandavam-se fazer fac-similes de algumas cartas, até para acompanhar as transcrições na edição do corpus, da mesma forma que se procuravam em arquivos estrangeiros alguns documentos, como no British Museum ou na biblioteca da universidade de Cambridge ${ }^{78}$.

Com ele trabalhava, pois, uma equipa de paleógrafos e de directores, que Herculano queria ver retribuídos sem cerceamentos, porque se dedicavam "aos áridos e tediosos trabalhos" que os Monumentos Históricos exigiam ${ }^{79}$. Nela se destacava o seu fiel companheiro de viagens e colaborador José Costa Basto, a quem o Mestre - assim lhe chamava o referido paleógrafo - teceu os maiores louvores ${ }^{80}$.

Herculano dirigia a Colecção em nome da Academia e, por isso, assim o diz, não era o seu nome que aparecia no rosto dos volumes, mas sim o da instituição. Em momento de dificuldade de financiamento da obra acrescenta mesmo, na sua linguagem de homem familiarizado com a terra ${ }^{81}$ : "não tenho feito mais do que ir arroteando os pousios para onde ela mandou o operário. Recebo a paga: dei o trabalho. Nem todos neste mundo fazem assim. O que ahi houver bom é della, que o comprou; minha só é a responsabilidade dos defeitos de execução" 82 . Desempenhou esta incumbência - apenas interrompida temporariamente pelos incidentes já referidos - até 1873, logo quase até à sua

${ }^{77}$ Idem, ibidem, p. 141. Por isso, logo no início da primeira viagem, queria que o Livro Preto da Sé fosse chamado a Lisboa "para verificar as citações das folhas delle na copia da Academia, que não reputo sempre exactas á vista do original”. (Carta de 6 de Julho de 1853).

${ }^{78}$ Alexandre Herculano, Cartas, t. I, p. 265-266, 281-283.

${ }^{79}$ Alexandre Herculano, Cartas, t. I, p. 277. Pela carta à Academia de 24 de Novembro de 1854 sabemos que João Pedro da Costa Basto trabalhava nos monumentos narrativos, tendo percorrido os manuscritos de Alcobaça e corrigido erros da Monarquia Lusitana, e que era muito competente, havendo lido o Livro da Noa, em impressão, e o Indiculum de S. Vicente em vinte e poucos dias.

${ }^{80}$ Na carta de 6 de Julho de 1853, referente a Coimbra, escreve: "sem a perícia e a constancia no trabalho do meu ajudante o $\mathrm{Snr}^{\circ}$ Basto não haveria alcançado ainda concluir o exame do vasto archivo capitular". Já na missiva de 30 de Julho de 1854, aludindo ao trabalho de investigação, assinalava: "olhe V. Excia. que eu sou desembaraçado nesta cousas e o Basto não o é menos do que eu".

${ }^{81}$ Lembremos que Herculano, desiludido com a política, arrendara de parceria a Granja do Calhariz desde 1854, vindo mesmo a adquirir depois a quinta de Vale de Lobos, perto de Azóia, no concelho de Santarém, em 1859. Já como homem casado, desde 1867, para ela se virá a retirar, entregando-se à produção de azeite, comercializado pela firma Jerónimo Martins, que virá até a receber prémios em exposições industriais, como na Exposição Universal de Paris, em 1876.

${ }^{82}$ Alexandre Herculano, Cartas, t. I, p. 278. 
morte, ocorrida em $1877^{83}$. Naquele ano entregou ao seu principal colaborador, José Manuel da Costa Basto, todo o acervo de transcrições e notas que tinha em mãos, como a sua integridade lho exigia, já que, sendo subsidiado, tal não era sua propriedade, além de especificar o material em tipografia ${ }^{84}$.

Logo naquele tempo a publicação mereceu elogios internacionais. Em carta à Academia Herculano disso dá testemunho, escrevendo: "a imprensa na Allemanha e na França tem applaudido a encetada publicação" e a Espanha "inveja o commettimento e a prossecução de uma obra a que alli, apesar dos esforços e da generosa cooperação do Governo, não pôde dar principio ainda" "85.

Também nos nossos dias, qualquer estudioso dos tempos medievais presta a melhor homenagem que se pode render à dita obra - serve-se dela. E isto sem se negar que estes Monumentos Históricos de Portugal, como toda e qualquer recolha documental, particularmente desta envergadura, contém omissões.

Pela voz autorizada de um dos mais significativos continuadores da Colecção, Rui Pinto de Azevedo, que lhe dirige aliás os maiores encómios, enunciam-se as faltas, mas sobremaneira os caminhos a percorrer, em estudo publicado em $1954^{86}$.

Queria este erudito que se divulgassem nos Scriptores as fontes árabes e se actualizasse a edição dos anais e antigos cronicões, bem como os Livros de Linhagem e Nobiliários.

Sem enunciar significativas lacunas nas Leges et Consuetudines, aponta apenas a omissão nelas das cartas de povoação, dado o critério juricista da recolha.

As maiores observações dizem respeito aos Diplomata et Chartae. Rui de Azevedo pretendida que fossem publicados os documentos pontifícios do século XII, tarefa que via facilitada pelos trabalhos de Carl Erdmann. Mais acrescentava que, se haviam sido publicados 952 documentos dos séculos IX a XI, nesse conjunto faltavam, no entanto, mais 374 cartas, para além de já se

\footnotetext{
${ }^{83}$ A carta de demissão dirigida à Academia data de Vale de Lobos, 1 de Abril de 1873 (Alexandre Herculano, Cartas, t. I, p. 284-286).

${ }^{84}$ Entrega então "as copias, conferidas com os originaes, dos mais notáveis necrológios das sés, collegiadas e antigos mosteiros, na parte desses necrológios anterior ao século XVI, e bem assim certa porção de notas minhas que devia acompanhá-los na sua publicação". Estava então a imprimir-se o índice do volume primeiro das Leges et Consuetudines, encontravam-se impressas 26 folhas do volume segundo da mesma série e também 25 folhas dos Diplomata et Chartae (Alexandre Herculano, Cartas, t. I, p. 284-286).

${ }^{85}$ Alexandre Herculano, Cartas, t. I, p. 278.

${ }^{86}$ Rui Pinto de Azevedo, "Herculano e os 'Portugaliae Monumenta Historica"”, in "História de Portugal” de Alexandre Herculano. Comemoração do Centenário da primeira edição, Lisboa, Academia Portuguesa da História, 1954, p. 39-46.
} 
conhecerem 15 originais de documentos aí lidos por cópias. Mas logo acrescentava que não era sua intenção "por forma alguma deslustrar o trabalho de compilação de fontes para o apontado volume, tanto mais que mais de trezentos documentos provém(vinham) do Cabido de Braga que recusara o envio dos seus pergaminhos para a Torre do Tombo". Mais assinalava a duplicação de vinte documentos, insistindo também em certas incorrecções quanto à data textual ou crítica de outros, em especial os mais antigos.

Na verdade, a recolha, transcrição e análise crítica da documentação avulsa é uma tarefa muito complexa, que exige o labor aturado de uma equipa de especialistas. Assim se compreende que fosse justamente o eminente paleógrafo e diplomatista Rui de Azevedo a dar continuidade a este trabalho, sob o impulso da Academia Portuguesa da História, publicando os Documentos Régios do Conde D. Henrique a D. Afonso Henriques e os Documentos Particulares de 1101 a $1123^{87}$. E com a colaboração, em particular de Avelino de Jesus da Costa, publicaram-se também os Documentos de D. Sancho I.

A documentação régia continua a merecer a atenção dos estudiosos. A edição de muitas chancelarias - de D. Afonso III, D. Afonso IV, D. Pedro, D. João I, D. Duarte - e de Cortes - de D. Afonso IV, D. Pedro, D. Fernando, D. Duarte e algumas de D. Manuel - tem sido dada a lume, pelo esforço de muitos professores universitários, sob o patrocínio de diversos Centros de Investigação, mas este primacial núcleo documental está longe de estar concluído.

A publicação dos documentos particulares, como colecção em si mesma, não foi continuada. É evidente que foram editadas grande colectâneas documentais em torno dos Descobrimentos, da figura de D. Henrique, da Universidade ou das Misericórdias. Do mesmo modo diversos livros sobre instituições eclesiásticas do clero regular e secular têm vindo a publicar, juntamente com os estudos, completos diplomatários, bem como múltiplos cartulários e tombos têm sido dados à estampa.

No que diz respeito às Leges et Consuetudines, a legislação régia viu-se republicada e ampliada até ao reinado de D. Afonso IV na edição do Livro de Leis e Posturas, do mesmo modo que estão ao dispor as Ordenações de D. Duarte e as Afonsinas, mas já quanto à lei local carecemos ainda, entre outra, da publicação dos forais de D. Dinis.

${ }^{87}$ Dispensamo-nos de abonar por completo esta colectânea de fontes e as demais que se seguem, remetendo o leitor para as citações de quase todas elas que se encontram nos estudos da obra de Maria Helena da Cruz Coelho, Maria José Azevedo Santos, Saul António Gomes, Maria do Rosário Morujão, Estudos de Diplomática Portuguesa, Lisboa, Edições Colibri-FLUC, 2001. 
No âmbitos dos Scriptores promoveu louvavelmente a Academia das Ciências de Lisboa a nova edição dos Livros de Linhagens, enquanto, de uma forma avulsa, foram republicados os mais antigos anais e crónicas, hagiografias, livros de milagres e obituários.

No que diz respeito às Inquirições, terminada a publicação das de D. Afonso III de 1258, a Academia das Ciências reabriu, há três anos, esta secção com a edição das Inquirições Gerais de D. Dinis de 1284, trabalho que está a ser continuado.

$\mathrm{Na}$ verdade, quando se comemoraram, no ano transacto, duzentos anos sobre o nascimento do reputado investigador, historiador e académico que foi Alexandre Herculano, julgamos que a melhor homenagem que lhe pode ser feita é a de prolongarmos a sua obra.

A ciência histórica não pode prescindir das fontes. Fontes em toda a sua abrangência de sentido, bem entendido, mas entre as quais os monumentos escritos adquirem um subido valor. $\mathrm{Na}$ verdade, um credível e profundo movimento de renovação científica tem de estar cimentado nos monumenta, património e memória, que, no caso dos mais significativos manuscritos, se devem editar com todo o rigor diplomático e paleográfico.

A acção do probo historiador, do eminente documentalista e do empenhado cidadão que foi Alexandre Herculano deve, pois, reproduzir-se.Assim acontecerá na dedicação e trabalho em prol da ciência da História e dos Documentos que, em toda a sua amplidão, constituem um meritório serviço à comunidade científica e um vivo comprometimento com a cidadania. 